NUREG-0390

Vol. 11

\title{
Topical Report Review Status
}



\section{U.S. Nuclear Regulatory Commission}

Office of Nuclear Reactor Regulation

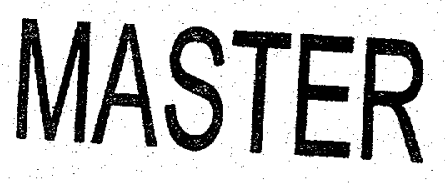




\section{AVAILABILITY NOTICE}

\section{Availability of Reference Materials Cited in NRC Publications}

Most documents cited in NRC publications will be available from one of the following sources:

1. The NRC Public Document Room, 2120 L Street, NW." Lower Level, Washington, DC 20555-0001

2. The Superintendent of Documents, U.S. Government Printing Office, P. O. Box 37082, Washington, DC 20402-9328

3. The National Technical Information Service, Springfield, VA 22161-0002

Although the listing that follows represents the majority of documents cited in NRC publications, it is not intended to be exhaustive.

Referenced documents available for inspection and copying for a fee from the NRC Public Document Room include NRC correspondence and internal NRC memoranda; NRC bulletins, circulars, information notices, inspection and investigation notices; licensee event reports; vendor reports and correspondence; Commission papers; and applicant and licensee documents and correspondence.

The following documents in the NUREG series are available for purchase from the Government Printing Office: formal NRC staff and contractor reports, NRC-sponsored conference proceedings, international agreement reports, grantee reports, and NRC booklets and brochures. Also available are regulatory guides, NRC regulations in the Code of Federal Regulations, and Nuclear Regulatory Commission Issuances.

Documents available from the National Technical Information Service include NUREG-series reports and technical reports prepared by other Federal agencies and reports prepared by the Atomic Energy Commission, forerunner agency to the Nuclear Regulatory Commission.

Documents available from public and special technical libraries include all open literature items, such as books, journal articles, and transactions. Federal Register notices, Federal and State legislation, and congressional reports can usually be obtained from these libraries.

Documents such as theses, dissertations, foreign reports and translations, and non-NRC conference proceedings are available for purchase from the organization sponsoring the publication cited.

Single copies of NRC draft reports are available free, to the extent of supply, upon written request to the Office of Administration, Distribution and Mail Services Section, U.S. Nuclear Regulatory Commission, Washington DC 20555-0001.

Copies of industry codes and standards used in a substantive manner in the NRC regulatory process are maintained at the NRC Library, Two White Flint North, 11545 Rockville Pike, Rockville, MD 20852-2738, for use by the public. Codes and standards are usually copyrighted and may be purchased from the originating organization or, if they are American National Standards, from the American National Standards Institute, 1430 Broadway, New York, NY 10018-3308. 


\section{Topical Report Review Status}

Manuscript Completed: July 1997

Date Published: August 1997

Division of Inspection and Support Programs

Office of Nuclear Reactor Regulation

U.S. Nuclear Regulatory Commission

Washington, DC 20555-0001



\section{DISCLAIMER}

This report was prepared as an account of work sponsored by an agency of the United States Government. Neither the United States Government nor any agency thereof, nor any of their employees, make any warranty, express or implied, or assumes any legal liability or responsibility for the accuracy, completeness, or usefulness of any information, apparatus, product, or process disclosed, or represents that its use would not infringe privately owned rights. Reference herein to any specific commercial product, process, or service by trade name, trademark, manufacturer, or otherwise does not necessarily constitute or imply its endorsement, recommendation, or favoring by the United States Government or any agency thereof. The views and opinions of authors expressed herein do not necessarily state or reflect those of the United States Government or any agency thereof. 


\section{DISCLAMmer}

Portions of this document may be illegible in electronic inage products. Images are produced from the best available original document. 


\section{ABSTRACT}

This report provides industry with procedures for submitting topical reports, guidance on how the U.S. Nuclear Regulatory Commission (NRC) processes and responds to topical report submittals, and an accounting, with review schedules, of al1 topical reports currently accepted for review by the NRC.

This report will be published annually. Each sponsoring organization with one or more topical reports accepted for review receives copies. 


\section{CONTENTS}

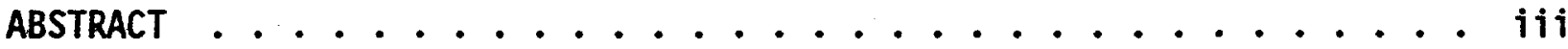

NUCLEAR REGULATORY COMMISSION LICENSING TOPICAL REPORT PROGRAM $\ldots$ - • . 1

LICENSING TOPICAL REPORT PROGRAM MANAGEMENT . . . . . . . . . . . . . . 1

PROCEDURE FOR SUBMITTING LICENSING TOPICAL REPORTS . . • . . . . . • . 1

Submittal of Reports for Review . . . . . . . . . . . . . 1

Copy Requirements ..................... 1

FORMAT OF LICENSING TOPICAL REPORTS . . . . . . . . . . . . . 2

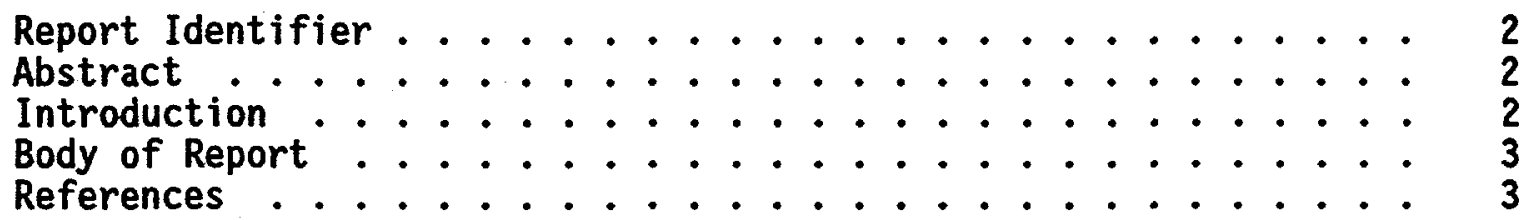

CRITERIA FOR ACCEPTING NEW LICENSING TOPICAL REPORTS FOR REVIEW . . . . . 3

HANDLING OF PROPRIETARY REPORTS .................... 4

CORRESPONDENCE FROM SPONSORING ORGANIZATION PERTAINING TO REPORTS . . . . 5

NRC REQUESTS FOR ADDITIONAL INFORMATION DURING REVIEW CYCLE . . . . . • 5

TRANSMITTAL OF NRC EVALUATION OF REPORTS . . . . . . . . . . . . . 5

PUBLICATION OF APPROVED VERSION OF REPORTS . . . . . . . . . . . . 5

PLACEMENT OF REPORTS AND ASSOCIATED DOCUMENTS IN PUBLIC DOCUMENT ROOM • • 5

REVISIONS TO REPORTS . . . . . . . . . . . . . . . . . 6

WITHDRAWAL OF REPORTS ........................ 6

APPENDIX . . . . . . . . . . . . . . . . . . . . . 7

EXPLANATION OF APPENDIX .................... 8

TOPICAL REPORTS ACCEPTED FOR REVIEW. . . . . . . . . . . . 9 


\section{NUCLEAR REGULATORY COMMISSION LICENSING TOPICAL REPORT PROGRAM}

Under the Nuclear Regulatory Commission (NRC) licensing topical report program, industry organizations may, on their own volition or at the request of the NRC staff, submit reports to the NRC on specific safety-related subjects and have them reviewed independently of any construction permit or operating license review. The purpose of this program is to minimize time and effort required of both industry and the NRC by providing for a single review and approval of the safety-related subject with subsequent referencing in 1 icensing actions, rather than repetitive reviews of the same subject. The reports currently accepted for review are given in the appendix.

Pursuant to Part 170 of Title 10 of the Code of Federal Regulations, applications for topical report reviews are subject to fees based on the ful1 cost of the review.

\section{LICENSING TOPICAL REPORT PROGRAM MANAGEMENT}

A topical report program manager (PM) manages and coordinates the overall program. Each review branch with responsibility for the detailed technical review of a specific report assigns review specialists who report to their own management on the detailed technical review matters.

PROCEDURE FOR SUBMITTING LICENSING TOPICAL REPORTS

Submittal of Reports for Review

A report (and requisite number of copies, as discussed below) submitted under the NRC licensing topical report program must be accompanied by a letter of transmittal. The first paragraph of this letter must include a statement that the applicant is submitting a licensing topical report under the NRC licensing topical report program for review and acceptance for referencing in licensing actions. This paragraph must specify the report identifier, title, and issue date. The transmittal letter and report should be addressed to the Document Control Desk, U.S. Nuclear Regulatory Commission, Washington, DC 20555-0001; ATTN: Chief, Information Management Branch, Division of Inspection and Support Programs. If a report is not sent to this address, there is no assurance that it will be entered into the agency's workload information and scheduling program database for tracking.

The transmittal letter should also include any pertinent information about the timeframe of the review and first referencing action. Al1 correspondence with the NRC concerning licensing topical reports or special reports should include the report identifier specified by the submitting organization in the upper right-hand corner of the transmittal letter.

\section{Copy Requirements}

Licensing topical reports must be submitted in hard copy in the following 
quantities. Additional copies will be provided to the NRC staff upon request.

\begin{tabular}{lc} 
Report Classification & Hard Copy \\
\hline Nonproprietary reports & 15 \\
Proprietary reports & 15 \\
Proprietary version & 12 \\
Nonproprietary version &
\end{tabular}

These quantity requirements pertain to all review submittals including initial submittals, revisions, supplements, responses to requests for additional information, and NRC-approved versions.

FORMAT OF LICENSING TOPICAL REPORTS

Report Identifier

Each licensing topical report should have a unique alphanumeric identifier for filing and reference purposes that is assigned to it by the submitting organization. The report identifier should be typed in the upper right-hand corner of the first page or cover page of all documents relating to the report.

Each organization submitting licensing topical reports should consult with the NRC topical report PM to ensure that the identifier it selects does not conflict with that of another organization. The identifier for all proprietary reports should have "-P" or "(P)" at the end. Each nonproprietary version of a proprietary report should have the same identifier as the corresponding proprietary report except that "-NP" or "(NP)" should be included at the end. NRC-approved versions of topical reports should have "-A" after the identifier ("-P-A" for approved proprietary reports).

A11 responses to NRC comments or requests for additional information regarding a specific licensing topical report should be identified by both the NRC technical assignment control (TAC) number and the submitting organization's identifier for that report followed by "Response to Comment," "Response to Request for Additional Information by the NRC Staff," or if appropriate, "Response by Appendix or Supplement to the Original Report." The use of an addendum is discouraged. It is possible that only a revision to the original report can constitute a response. This is acceptable when appropriate. However, each revision will entail a new review, and the old review will be closed out.

\section{Abstract}

Each report should include an abstract no longer than one page that summarizes the contents of the report and the conclusions reached.

\section{Introduction}

Each report should have an introductory section that gives the purpose of the report and clearly defines its scope and applicability. Any limitations or restrictions on the use of the report or its results or conclusions as determined by either the staff or the sponsoring organization should also be listed in this section. 


\section{Body of Report}

The body of each report may be organized at the discretion of the sponsoring organization to suit its needs and the subject matter of the report. It is recommended that long tabulations of data such as test results, computer program descriptions, detailed technical analyses, or derivations be included as appendices.

\section{References}

Each report should include a 1 ist of all pertinent references.

\section{CRITERIA FOR ACCEPTING NEW LICENSING TOPICAL REPORTS FOR REVIEW}

The cognizant technical review organization screens reports submitted for review under the licensing topical report program in accordance with the following criteria. No new report submitted by any organization will be accepted as a licensing topical report unless the cognizant technical review organization determines that it qualifies as such. In making such a determination all four of the following criteria should be met:

(1) The report deals with a specific "safety-related" subject regarding a nuclear power plant that requires a safety assessment by the NRC staff, such as component design, analytical models or techniques, or performance testing of components and/or systems that can be evaluated independently of any specific license application.

(2) The report is, or is expected to be, referenced in a number of ticense or standardized reference design approval applications.

(3) The report contains complete and detailed information on the specific subject presented. Conceptual or incomplete preliminary information will not be reviewed.

(4) NRC approval of the report will result in increased efficiency of the review process for applications that reference the report.

Licensing topical reports that present a new design or procedure not currently addressed in any license or standardized reference design approval application require special consideration. In support of such a report, the sponsoring organization must submit documentation from at least two potential applicants of their intent to reference the report before the NRC commits resources to perform the review. It is not the intent of the licensing topical report program to provide engineering evaluations of feasibility, economics, or desirability of material submitted that could directly or indirectly be used in sales promotion efforts.

Exceptions to these acceptance criteria may be allowed. These exceptions must be based on an NRC decision that it is in the public interest to evaluate a proposed licensing topical report. The sponsoring organization should provide the NRC with justification for such exceptions. This may include such items as cost savings to the industry if implemented, or a consideration of whether the 
evaluation would contribute to the formation of a broader base for resolving a present or developing safety-related subject generally evidenced by experience from operating nuclear power plants. As an example, a proposed 1icensing topical report on a new pump design might be accepted for review if experience at operating nuclear power plants indicated that currently installed pumps might be expected to infringe on the margins of safety to an unacceptable degree, and the new pump design might reasonably be expected to remedy the problem.

These exceptions will include a determination that NRC staff resources expended in the review of the licensing topical report will provide a foreseeable benefit equal to or greater than the impact from redirection and reduction of resources committed to other ongoing license actions, licensing topical report reviews, or generic technical issues.

When a sponsoring organization is planning a report that it believes can qualify as a licensing topical report, it should contact the topical report PM we11 in advance of the planned submittal to determine if the proposed report will satisfy the definition of a licensing topical report and, if so, to clarify the requirements for preparing and submitting the report. A meeting might be appropriate to discuss these issues. The topical report PM, in consultation with the staff technical specialists and management, will make a timely determination on the qualifications of the proposed report. If the report qualifies as a licensing topical report, the sponsoring organization may then formally submit it for review.

The NRC may also find that addressing a safety-related matter in a licensing topical report is desirable. In such a case, NRC management will contact the sponsoring organization and discuss the preparation of such a report. If the organization agrees to prepare it, they will formally submit it for review.

Other types of reports that do not meet the criteria for licensing topical reports may be submitted as special reports.

If accepted for review under the licensing topical report program, the report will be 1isted in the appendix to this NUREG series report. If the report is rejected for review, the sponsoring organization will be notified of this decision.

\section{HANDLING OF PROPRIETARY REPORTS}

When an organization submits a licensing topical report for NRC review pursuant to this NUREG series report and believes that portions of the report contain confidential business (proprietary) information, it must submit at least 12 copies of a nonproprietary version of the proprietary report at the same time it submits the proprietary report. The proprietary report must show which portions are proprietary by the use of italics or margin lines or by underscoring or bracketing the proprietary material. A nonproprietary report should show what information has been deleted from the proprietary version because the submitting organization considers it to be proprietary. For example, if brackets are used in the proprietary version to show what portion of the information is considered proprietary, the nonproprietary version should have a blank portion between the brackets to show that information was removed. Upon submittal of a properly 
marked 1icensing topical report (see Section 2.790 of Title 10 of the Code of Federal Regulations) considered and justified as proprietary, the NRC will determine whether or not the information should be withheld from public disclosure and will notify the submitting organization accordingly.

\section{CORRESPONDENCE FROM SPONSORING ORGANIZATION PERTAINING TO REPORTS}

Al1 correspondence regarding 1 icensing topical reports should be addressed to the Document Control Desk, U.S. Nuclear Regulatory Commission, Washington, DC 205550001; ATTN: Chief, Information Management Branch, Division of Inspection and Support Programs, and should contain both the appropriate report identifier and NRC TAC number in the upper right-hand corner.

\section{NRC REQUESTS FOR ADDITIONAL INFORMATION DURING REVIEW CYCLE}

The NRC may request additional information on a licensing topical report under review either during a meeting or by letter. The chief of the technical review branch will transmit to the sponsoring organization written requests for additional information (RAIs) on licensing topical reports. The sponsoring organization will submit its responses to these requests and to staff comments during the review as information supplementary to the original report. Requests for additional information and responses to RAIs shall be documented in the approved version of the topical report (see below). The technical review branch will schedule meetings with the sponsoring organization to discuss the contents of a licensing topical report.

\section{TRANSMITTAL OF NRC EVALUATION OF REPORTS}

When the NRC determines that a licensing topical report is acceptable for referencing, it will give the extent of and the conditions for acceptance, if any, in a letter transmitting the results of the evaluation. For a proprietary report, the transmittal letter will state that both proprietary and nonproprietary versions must be referenced in future 7 icense applications. The NRC evaluation and letter of transmittal will be incorporated in the accepted version of the report when submitted.

\section{PUBLICATION OF APPROVED VERSION OF REPORTS}

After the NRC accepts a licensing topical report for referencing, the sponsoring organization should publish an approved version. A copy of NRC's transmittal letter and its evaluation report should be inserted immediately after the title page of the approved version. Immediately after the transmittal letter and evaluation report, all RAIs and responses to RAIs also should be inserted.

\section{PLACEMENT OF REPORTS AND ASSOCIATED DOCUMENTS IN PUBLIC DOCUMENT ROOM}

All nonproprietary correspondence regarding the review of 1 icensing topical reports, a11 nonproprietary 1 icensing topical reports, and al1 nonproprietary versions of proprietary reports will be placed in the NRC Public Document Room (PDR) 1ocated at 2120 L Street, N.W. , Washington DC; telephone (202) 634-3273. The sponsoring organization and the NRC should exercise care to ensure that any information identified as proprietary by the sponsoring organization is not used 
in any of the above correspondence and in licensing topical report evaluations. Licensing topical reports are not placed in local PDRs; however, nonproprietary versions are available on request.

\section{REVISIONS TO REPORTS}

After a licensing topical report has been found acceptable for referencing, the sponsoring organization occasionally might need to add supplementary information to keep it up to date. This is different from the situation where the report has become obsolete and must be withdrawn. A proposed revision to an approved report is submitted to and reviewed by the NRC in accordance with the same requirements and procedures as those that apply to a new licensing topical report. The revision will have the same identifier as the base report with the suffix "Revision 1 or 2," etc. However, the NRC topical report PM will issue a new NRC TAC number. When a revision to an accepted report is submitted for review, the "A" designation is not included as part of the identifier. The approved report may remain acceptable for referencing.

When the NRC determines that the revised or supplementary material is acceptable for referencing, the sponsoring organization will submit the required number of complete new reports incorporating the revised or supplementary information. The revised report must contain a note on the cover page stating that it supersedes and replaces all earlier versions of the same numbered report. The superseded reports will not be returned to the sponsoring organization.

\section{WITHDRAWAL OF REPORTS}

After a certain amount of time has elapsed, a 1 icensing topical report may become obsolete, as determined by either the NRC or the sponsoring organization, because it does not adequately address the current state of the technology, or it is no longer applicable because NRC criteria or regulations have changed, or for other reasons. In this event, the sponsoring organization may, on its own volition, request that the report be withdrawn or the NRC may advise the sponsoring organization to do so. On receipt of a letter from a sponsoring organization requesting withdrawal of a 1 icensing topical report, the $\mathrm{NRC}$ will categorize it as "withdrawn." Withdrawn reports are not acceptable as references in license applications. The report may be replaced by an updated or new licensing topical report that has a new identifier and new NRC TAC number to avoid confusion with the withdrawn report. 


\section{APPENDIX}

TOPICAL REPORTS ACCEPTED FOR REVIEW BY THE NRC STAFF 


\section{EXPLANATION OF APPENDIX}

TASK ID

Technical Assignment Control (TAC) number used for tracking purposes

REV

TITLE

Name of the organization reviewing the topical report

APPL DATE

Name of the topical report

SCHEDULE ACT

START

Date of the letter transmitting the topical report to NRC

TR COMP

Planned or actual technical review start date

ACTION COMPLETE Date of document which closes action on the topical report (NRC letter of approvai or rejection, sponsoring organization letter of withdrawal)

ACT HOURS

Staff hours that have been charged in the review of a topical report

SCH REM HOURS Remaining number of scheduled staff hours to complete review of topical report

APPL ACCESSION Accession number given the letter transmitting the topical report when submitted to NRC for review

$X=\quad$ Cancelled

$H=\quad$ Hold

$\mathrm{L}=\quad$ Target Date Passed

$\mathrm{C}=$. Complete

$X(C R)=\quad$ Scheduled at a constant rate of $x$ hours per week; i.e., 4 (CR) indicates 4 hours per week

Unassigned $=\quad$ Not yet assigned to a reviewer in organization shown

Suppressed $=$ Reviewer currently not on NRR staff

NOTES:

- The appendix does not reflect contractor costs.

- The estimates shown in the appendix are based on workload and resource projections that are focused on the next 6 months. Priority of a review task is determined primarily. on the basis of safety significance, risk considerations, and operational impact. Schedules are subject to change in the event of higher priority, safety-related issues. 
Taskid Rev. Title

M87910 CENPD-289-P, JUSTIFYING USE OF INSERT REPLACEMENT RODS IN ABB CENF FUEL ASSEMBLIES .

\section{SRXBA}

SRXBA

M89487

CENPD-290-P - ABB BWR GENERIC CONTROL ROD DESIGN METHODOLOGY

SRXBA

6

M92981

CENPSD 994,995,996 (PROJ 692) - C-E OWNERS GROUP - JOINT APPLICATION

REPORTS FOR TECH SPEC AOT EXTENSIONS

ATSBA

ATSBA

EELBA

SPSBB

SPSBB

SRXB

SRXBB

SRXBB
M95174

CENPSD 985, REV. 1 (PROJ 692) CREDITING SOLUBLE BORON IN LWR SFPS
SRXBB

\begin{tabular}{|c|c|c|c|c|c|c|}
\hline & Schedul & & & & Sch. & \\
\hline $\begin{array}{l}\text { Appl } \\
\text { Date }\end{array}$ & $\begin{array}{l}\text { Act } \\
\text { Start }\end{array}$ & $\begin{array}{l}\text { TR } \\
\text { Complete }\end{array}$ & $\begin{array}{l}\text { Action } \\
\text { Complete }\end{array}$ & $\begin{array}{l}\text { Act. } \\
\text { Hours }\end{array}$ & $\begin{array}{l}\text { Rem. } \\
\text { Hours }\end{array}$ & $\begin{array}{l}\text { Appl . } \\
\text { Accession }\end{array}$ \\
\hline & $-\cdots$ & $\ldots$ & -- & & & \\
\hline
\end{tabular}

$(09 / 30 / 93)(01 / 01 / 94)(--/ \cdots / \cdots)(12 / 30 / 97 T)$

137

179310050224

$01 / 01 / 94 \quad 12 / 30 / 97$

$07 / 20 / 96 \quad 12 / 30 / 97$

$95 \quad 5$

$42 \quad 12$

$(02 / 16 / 94)(08 / 06 / 94)(--/ \cdots /-\cdots)(12 / 31 / 97 T)$

08/06/94 --/--/--H

31

09402280297

31

0

$(07 / 27 / 95)(08 / 05 / 95)(--/--/-)(12 / 26 / 97 T)$ 1159

3919508220084

$\begin{array}{ll}08 / 05 / 95 & 12 / 26 / 97 \\ 02 / 24 / 96 & --/--/-- \\ 09 / 16 / 95 & 06 / 30 / 97 \mathrm{~L} \\ 09 / 09 / 95 & 09 / 04 / 97 \\ 10 / 14 / 95 & 08 / 30 / 97 \\ 09 / 23 / 95 & 09 / 17 / 96 \mathrm{X} \\ 09 / 16 / 95 & 04 / 04 / 97 \mathrm{C} \\ 12 / 02 / 95 & 11 / 13 / 96 \mathrm{C}\end{array}$

$385 \quad 154$

940

$125 \quad 0$

$121 \quad 97$

$229 \quad 140$

10 ...

186

$12 / 02 / 95 \quad 11 / 13 / 96 \mathrm{C}$

$(04 / 05 / 96)(05 / 25 / 96)(--/--/--)(05 / 04 / 98 T)$ 


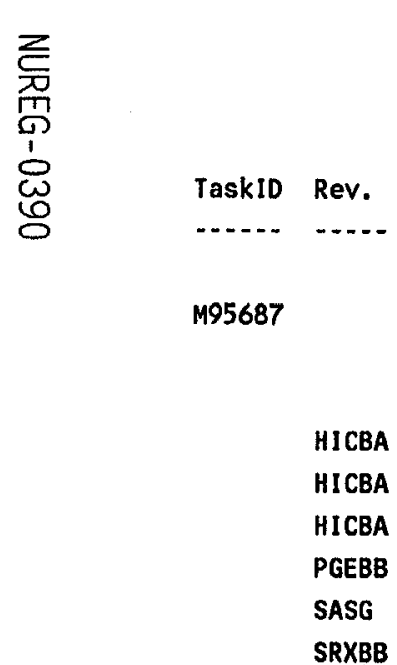

Report Date

$07 / 24 / 97$

\begin{tabular}{|c|c|c|c|c|c|c|}
\hline \multirow{2}{*}{ Appl } & \multicolumn{3}{|c|}{ Schedule } & \multicolumn{3}{|c|}{ Sch. } \\
\hline & $\begin{array}{l}\text { Act } \\
\text { Start }\end{array}$ & $\begin{array}{l}\text { TR } \\
\text { Complete }\end{array}$ & $\begin{array}{l}\text { Action } \\
\text { Complete }\end{array}$ & $\begin{array}{l}\text { Act. } \\
\text { Hours }\end{array}$ & $\begin{array}{l}\text { Ren. } \\
\text { Hours }\end{array}$ & $\begin{array}{l}\text { Appl. } \\
\text { Accession }\end{array}$ \\
\hline & - & 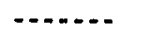 & $\ldots$ & & & 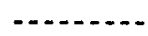 \\
\hline
\end{tabular}

CENPD - 137, SUPPLEMENT 2-P - CALCULATIVE

$(05 / 23 / 96)(06 / 15 / 96)(--/ \cdots / \cdots)(11 / 14 / 97 T)$

500

369605300046 METHODS FOR ABB-CE SMALL BREAK LOCA EVALUATION MODEL

HICBA

PGEBB

SRXBB

\section{$07 / 13 / 96 \quad 07 / 26 / 96 \mathrm{C}$}

$--/--1-0 \quad 01 / 28 / 97 \mathrm{C}$

$07 / 13 / 96 \quad 08 / 30 / 96 x$

$--/--1-. \quad 07 / 31 / 97$

$10 / 05 / 96 \quad 11 / 14 / 97$

$06 / 15 / 96 \quad 08 / 29 / 97$

$\begin{array}{rr}71 & \ldots \\ 0 & \ldots \\ 11 & \ldots \\ 0 & 1 \\ 129 & 21 \\ 289 & 14\end{array}$



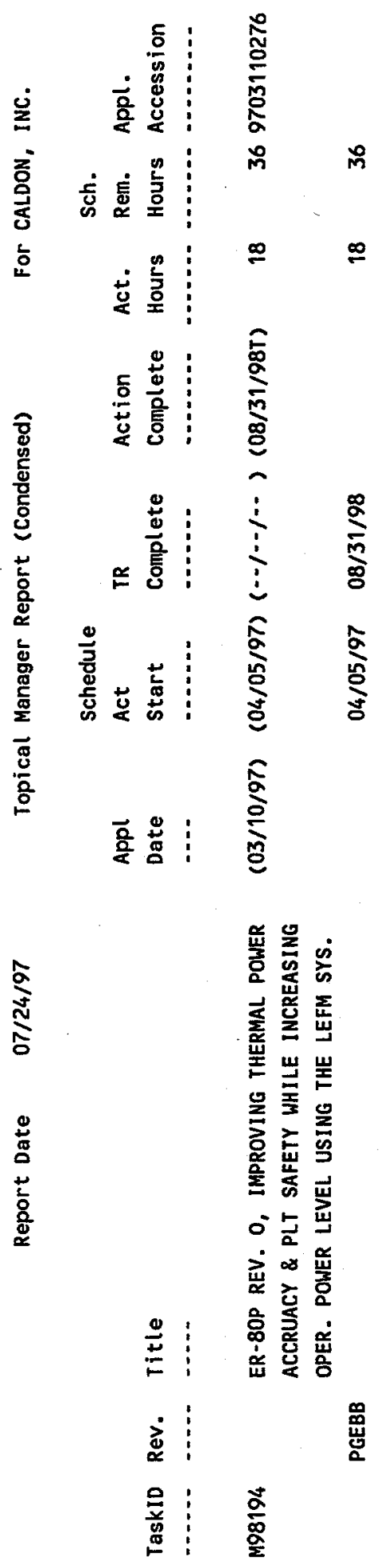
TaskID Rev. Title

-...... -.... ......

$M 92914$

NFSR-0111 - BUR TRANSIENT ANALYSIS

METHODS TOPICAL REPORT

HQMBB

SRXBA
Schedule

Act $T$

TR

Appl

\section{Date}

start

Complete

Action

....

(n......

(........

Act. Rem. Appl.

Hours Hours Accession

$(06 / 26 / 95)(08 / 19 / 95)(--/--/--)(08 / 31 / 971)$

347

729507060338

$11 / 11 / 95$

$11 / 04 / 95$

$01 / 05 / 96 \mathrm{C}$

$01 / 26 / 95 \mathrm{X}$

Suppressed

26

$08 / 19 / 95$

$08 / 31 / 97$

318

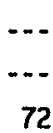


Report Date 07/24/97

TaskID Rev. Title

...... -.... ....

M96731

EPRI NP 7480-L, ADDENDUM 1 - SG TUBING OUTSIDE DIAMETER STRESS CORROSION

CRACKING AT TUBE SPPRT. PLATES DATABASE

EMCBC

EMCBC

EMCBC
Topical Manager Report (Condensed)

Schedule

Appl

Date

$$
\text { Act }
$$

Start

TR

Complete

-......

(.......

Action

-...

Complete

Hour:

$(09 / 05 / 96)(10 / 19 / 96)(\cdots / \cdots / \cdots)(12 / 31 / 97 T) \quad 324 \quad 499609170236$

For ELECTRIC POWER RESEARCH INSTITUTE

Sch.

Rem. Appl.

hours Hours Accession

-....................

$(09 / 0$

$\begin{array}{lcrr}12 / 21 / 96 & 12 / 31 / 97 & 34 & 49 \\ 10 / 19 / 96 & \text { S(CR) } & 232 & \\ 12 / 21 / 96 & --/--/ \cdots & 58 & 0\end{array}$


TaskID Rev. Title

C................

M93346

BAW-10193P - RELAPS/MOD2-B\&W FOR SAFETY ANALYSIS OF B\&W- DESIGNED PWRS

SRXBB

M93638

BAW-2228P, REV 1, FRACTURE MECH. ASSESS. OF POSTULATED OUTERSURFACE, SEMI-ELLIP

CIRCUM RV NOZZLE-TO-PIPE WELD FLAWS

EMCB

EMCBA

PDST

$\stackrel{\bullet}{\oplus}$

\begin{tabular}{|c|c|c|c|c|c|c|}
\hline & Schedul & & & & Sch. & \\
\hline $\begin{array}{l}\text { Appl } \\
\text { Date }\end{array}$ & $\begin{array}{l}\text { Act } \\
\text { Start }\end{array}$ & $\begin{array}{l}\text { TR } \\
\text { Complete }\end{array}$ & $\begin{array}{l}\text { Action } \\
\text { Complete }\end{array}$ & $\begin{array}{l}\text { Act. } \\
\text { Hours }\end{array}$ & $\begin{array}{l}\text { Rem. } \\
\text { Hours }\end{array}$ & $\begin{array}{l}\text { Appl. } \\
\text { Accession }\end{array}$ \\
\hline & - & $\ldots$ & - & & $\cdots$ & 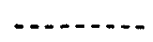 \\
\hline
\end{tabular}

$(08 / 14 / 95)(11 / 11 / 95)(--/--/-\cdots)(12 / 31 / 981)$

3

2039508180260

$11 / 11 / 95 \quad 12 / 31 / 98$

3

203

\begin{tabular}{|c|c|c|}
\hline $08 / 15 / 95)$ & $(10 / 07 / 95)$ & $(--/--/-)(12 / 31 / 97 T)$ \\
\hline & $02 / 10 / 96$ & 12/31/96L \\
\hline & $01 / 27 / 96$ & $03 / 21 / 96 \mathrm{C}$ \\
\hline & $10 / 07 / 95$ & $02 / 19 / 97 \mathrm{C}$ \\
\hline
\end{tabular}

68

09508300156

$10 / 07 / 95 \quad 02 / 19 / 97$

30

62

M94376

BAW-2245 - INITIAL RT-NOT OF LINDE 80

$(09 / 22 / 95)(02 / 10 / 96)(--/--/--)(12 / 31 / 971)$

201

09509270252 WELDS.

EMCB

EMCBA

03/02/96 --1/--/-- Suppressed

220

03/16/96 --1--1-

$02 / 10 / 96 \quad 06 / 13 / 96 \mathrm{C}$

PDST

05/18/96 02/19/97C

110

$166 \quad \ldots$ 


\section{Topical Manager Report (Condensed)}

Schedule

Taskid Rev. Title

Taskid Ren. Tith

M95773

BAW-10167P, SUPPLEMENT 3 - JUSTIFICATION FOR INCREASING REACTOR TRIP SYSTEM ONLINE TEST INTERVAL

HICBB

HICBB

PDST

PGEBB

SPSBB

SPSBB

它

M96727

BAW-10221P - NEMO - A KINETICS SOLUTION IN NEMO.

SRXBB

SRXBB

M96728

BAW-10199P, ADDENDUM 1 - BWU CRITICAL HEAT FLUX CORRELATIONS

SRXBA

\begin{tabular}{|c|c|c|c|c|c|c|}
\hline & Schedule & & & & Sch. & \\
\hline $\begin{array}{l}\text { Appl } \\
\text { Date }\end{array}$ & $\begin{array}{l}\text { Act } \\
\text { Start }\end{array}$ & $\begin{array}{l}\text { TR } \\
\text { Complete }\end{array}$ & $\begin{array}{l}\text { Action } \\
\text { Complete }\end{array}$ & $\begin{array}{l}\text { Act. } \\
\text { Hours }\end{array}$ & $\begin{array}{l}\text { Rem. } \\
\text { Hours }\end{array}$ & $\begin{array}{l}\text { Appl. } \\
\text { Accessior }\end{array}$ \\
\hline
\end{tabular}

$(06 / 25 / 96)(07 / 06 / 96)(--/-1--)(03 / 01 / 99 T)$

312

46

$08 / 03 / 96 \quad 05 / 03 / 97 \mathrm{C}$

$07 / 06 / 96 \quad--/--/--H$

--/--/-. 02/19/97C

$02 / 22 / 97 \quad 04 / 30 / 97 \mathrm{~L}$

$07 / 12 / 97 \quad 09 / 25 / 97$

$10 / 12 / 96 \quad 12 / 31 / 96 \mathrm{C}$

$(09 / 30 / 96)(10 / 19 / 96)(--/--/-\cdots)(12 / 31 / 97 \mathrm{~T})$

$-\cdots / \cdots / \cdots \quad 12 / 31 / 97$

$10 / 19 / 96 \quad 10 / 16 / 96 \mathrm{X}$

2

609610090315

60

2

$(09 / 30 / 96)(12 / 21 / 96)(--/--/ \cdots)(07 / 31 / 97 I)$

$54 \quad 69610090326$

$12 / 21 / 96 \quad 07 / 31 / 97$

54 


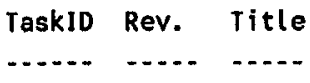

$M 77253$

NEDE-24011-P-A, AM 23 - GE STANDARD APPLICATION FOR REACTOR FUEL (GESTAR-11)

SRXBA

M85776

NEDC-32160-P - BWROG "CALIBRATION INTERVAL EXTENSION"

HICBA

HICBA

PGEBA

$\overrightarrow{0}$

$M 85913$

NEDE-32176-(P) - TRACG, MODEL DESCRIPTION, 2/93.

SASG

SCSB

SRXB

SRXBC

\section{Schedule}

Act

Appl

Date

Start

TR

Action

Sch

...... - ......

$(01 / 19 / 90)(01 / 04 / 92)(--/--/--)(10 / 12 / 98 T)$

11

59303300067

$01 / 04 / 92 \quad 10 / 12 / 98$

11

$(01 / 08 / 93)(05 / 01 / 93)(--/--/--)(12 / 31 / 97 T)$

458

1119302040080

$05 / 01 / 93 \quad 12 / 31 / 97$

$11 / 05 / 94 \quad 12 / 31 / 97$

$08 / 26 / 95 \quad--1 /--1-\cdot$

355

99

69

$(02 / 23 / 93)(03 / 13 / 93)(--/--/--)(01 / 02 / 98 T) 1166$

1329303030220

$\begin{array}{lllrl}05 / 18 / 96 & 10 / 02 / 96 \mathrm{C} & \text { suppressed } & 168 & \ldots . \\ 03 / 20 / 93 & 01 / 02 / 98 & 62 & 132 \\ 09 / 18 / 93 & 02 / 16 / 95 \mathrm{C} & 7 & \ldots \\ 04 / 08 / 95 & 05 / 15 / 96 \mathrm{C} & 10 & \ldots \\ 03 / 13 / 93 & 05 / 09 / 97 \mathrm{C} & 919 & \ldots\end{array}$


TaskID Rev. Title

Taskio Rev. Title

M85915

NEDE-32178-(P) - APPLIC. OF TRACG MODEL TO SBWR LICENSING SAFETY ANALYSES, $2 / 93$.

SASG

SCSB

SRXB

SRXBC

M87103

w

NEDE-32177-P - TRACG QUALIFICATION, REV 1, JUNE 1993.

PERBB

SRXBC

M87911

NEDC-31858-P, REV 2 - BWROG RPT FOR INCREASING MSIV LEAKAGE RATE LIMITS \&

ELIMINATION OF LEAKAGE CONTROL SYSTEMS

\begin{tabular}{|c|c|c|c|c|c|c|}
\hline & Schedule & & & & Sch. & \\
\hline $\begin{array}{l}\text { Appl } \\
\text { Date }\end{array}$ & $\begin{array}{l}\text { Act } \\
\text { Start }\end{array}$ & $\begin{array}{l}\text { TR } \\
\text { Complete }\end{array}$ & $\begin{array}{l}\text { Action } \\
\text { Complete }\end{array}$ & $\begin{array}{l}\text { Act. } \\
\text { Hours }\end{array}$ & $\begin{array}{l}\text { Rem. } \\
\text { Hours }\end{array}$ & $\begin{array}{l}\text { Appl. } \\
\text { Accession }\end{array}$ \\
\hline & 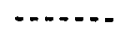 & $\cdots$ & 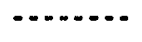 & $\ldots$ & 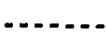 & - \\
\hline
\end{tabular}

$(02 / 25 / 93)(03 / 20 / 93)(--/--/-\cdot)(04 / 03 / 981) \quad 562$

1289303030233

$03 / 20 / 93 \quad 04 / 03 / 98$

$09 / 18 / 93 \quad 02 / 16 / 95 \mathrm{C}$

$04 / 08 / 95 \quad 05 / 15 / 96 \mathrm{C}$

$03 / 20 / 93 \quad 05 / 09 / 97 \mathrm{C}$

$(07 / 12 / 93)(08 / 28 / 93)(\cdots / \cdots / \cdots)(12 / 31 / 97 T) \quad 894$

$09 / 24 / 94 \quad 07 / 14 / 96 \mathrm{~L}$

$11 / 19 / 94 \quad 05 / 23 / 96 \mathrm{C}$

08/28/93 05/09/97C

140

71

809

$(09 / 01 / 94)(10 / 23 / 93)(--/--/-)(12 / 31 / 97 \mathrm{~T})$

$\begin{array}{lllrr}12 / 04 / 93 & 06 / 20 / 94 X & \text { suppressed } & 1 & \cdots \\ 05 / 11 / 96 & 07 / 31 / 97 & 30 & 43 \\ 03 / 01 / 97 & ---/--/--H & 14 & 0 \\ 10 / 23 / 93 & 05 / 27 / 94 \mathrm{C} & 3 & --- \\ 10 / 30 / 93 & --/--/-H & 399 & 0 \\ 02 / 11 / 95 & 05 / 31 / 97 \mathrm{~L} & 11 & 0 \\ 03 / 08 / 97 & --/--/-- & 36 & 0 \\ 12 / 17 / 94 & 04 / 30 / 96 \mathrm{C} & 5 & \cdots \\ 11 / 06 / 93 & 03 / 29 / 97 \mathrm{C} & 79 & \cdots\end{array}$


Task1D Rev. Title

M91528

MFN-118-94 - GE SAFETY LIMIT MCPR FOR GE 13 FUEL (JKF 94-14)

SRXBA

M95081

MFN-028-96 R-FACTOR CALCULATION METHOD AND GEXL CORRELATION

SRXBA

$\stackrel{\leftrightarrow}{\infty}$

M95087
NEDC-32523P GENERIC EVALUATIONS OF GE BWR EXTENDED POWER UPRATE

EMCBA

EMEBA

EMEBA

EMEBA

HICBB

PD31

PERBB

SCSB

SPLBA

SPSBB

SRXBA

\begin{tabular}{|c|c|c|c|c|c|}
\hline schedule & & & & Sch. & \\
\hline $\begin{array}{l}\text { Act } \\
\text { Start }\end{array}$ & $\begin{array}{l}\text { TR } \\
\text { Complete }\end{array}$ & $\begin{array}{l}\text { Action } \\
\text { Complete }\end{array}$ & $\begin{array}{l}\text { Act. } \\
\text { Hours }\end{array}$ & $\begin{array}{l}\text { Rem. } \\
\text { Hours }\end{array}$ & $\begin{array}{l}\text { Appl. } \\
\text { Accession }\end{array}$ \\
\hline$\cdots$ & 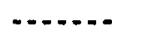 & .... & & $\cdots$ & \\
\hline
\end{tabular}

$\begin{array}{llllll}\text { Appl } & \text { Act } & \text { TR } & \text { Action } & \text { Act. } & \text { Rem. Appl. } \\ \text { Date } & \text { Start } & \text { Complete } & \text { Complete Hours Hours Accession }\end{array}$

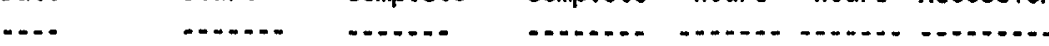

$(09 / 28 / 94)(04 / 01 / 95)(--/ \cdots / \cdots)(12 / 22 / 971)$

220

59410040252

$12 / 02 / 95 \quad 12 / 12 / 96 \mathrm{C} \quad$ Suppressed 24

04/01/95 08/01/97

196

5

$(02 / 26 / 96)(03 / 30 / 96)(\cdots / \cdots / \cdots)(09 / 04 / 97 T)$

319603050312

$07 / 06 / 96 \quad 09 / 04 / 97$

$03 / 30 / 96 \quad 07 / 31 / 97$

27

$91 \quad 24$

$(03 / 22 / 96)(03 / 30 / 96)(--/ \cdots / \cdots)(12 / 07 / 98 T)$

460

521

$07 / 06 / 96 \quad 12 / 07 / 98$

$04 / 06 / 96 \quad 10 / 30 / 97$

$11 / 02 / 96 \quad 01 / 07 / 97 \mathrm{C}$

$11 / 09 / 96 \quad--/ \cdots /--H$

$05 / 11 / 96 \quad 04 / 11 / 97 \mathrm{C}$

$03 / 30 / 96 \quad--/ \cdot-/ \cdots$

$12 / 07 / 96 \quad 03 / 15 / 98$

$08 / 10 / 96 \quad 09 / 05 / 97$

$05 / 11 / 96 \quad 05 / 18 / 96 \mathrm{C}$

$05 / 18 / 96 \quad 12 / 31 / 96 \mathrm{C}$

$06 / 15 / 96 \quad 12 / 31 / 97$
$7 \quad 40$

150

$8 \quad \cdots$

$95 \quad \ldots$

112

12

-..

207 
TaskID Rev. Title

-..... -.... ......

M95746

NEDC-32410P, SUPPL 1 - NUCLEAR

MEASUREMENT ANALYSIS\&CONTROL PWR RANGE

NEUTRON MONITOR RETROFIT PLUS OPT. III STABILI

ATSB

HICBA

PD13

PGEBA

M96730

๒ै

M97490

NEDC-32601P - METHODOLOGY \& UNCERTAINTIES FOR SAFETY LIMIT MCPR EVALUATIONS
NEDO-32339, SUPPL 5 - REACTOR STABILITY LONG-TERM SOLUTION: ENHANCED OPTION I-A SOLUTION CLOSURE.
$(09 / 26 / 96)(07 / 12 / 97)(--/--/ \cdots)(08 / 01 / 97 T)$

$07 / 12 / 97 \quad 08 / 01 / 97$

$(12 / 13 / 96)(--/--/--)(--/--/ \cdot)(11 / 21 / 97 \mathrm{~T})$

$--/--11 / 21 / 97$
Sch.

Action Act. Rem. Appl.

Complete Hours Hours Accession

$(05 / 24 / 96)(06 / 22 / 96)(--/ \cdots / \cdots)(09 / 10 / 97 T) \quad 177 \quad 89605290007$

$\begin{array}{ll}11 / 16 / 96 & --/--1- \\ 06 / 22 / 96 & 01 / 27 / 970 \\ 08 / 17 / 96 & --1--1- \\ 12 / 14 / 96 & 09 / 10 / 97\end{array}$

$\begin{array}{rr}7 & 0 \\ 161 & - \\ 1 & 0 \\ 8 & 8\end{array}$




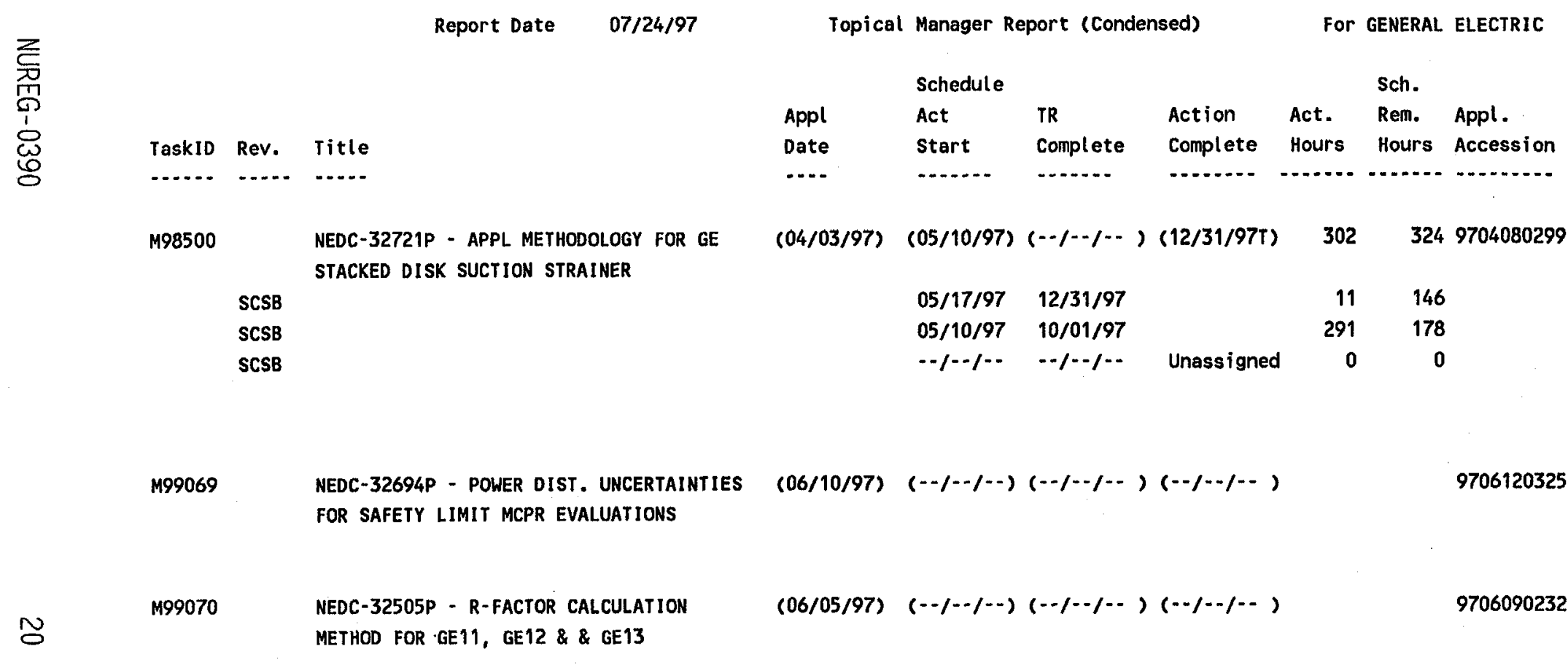



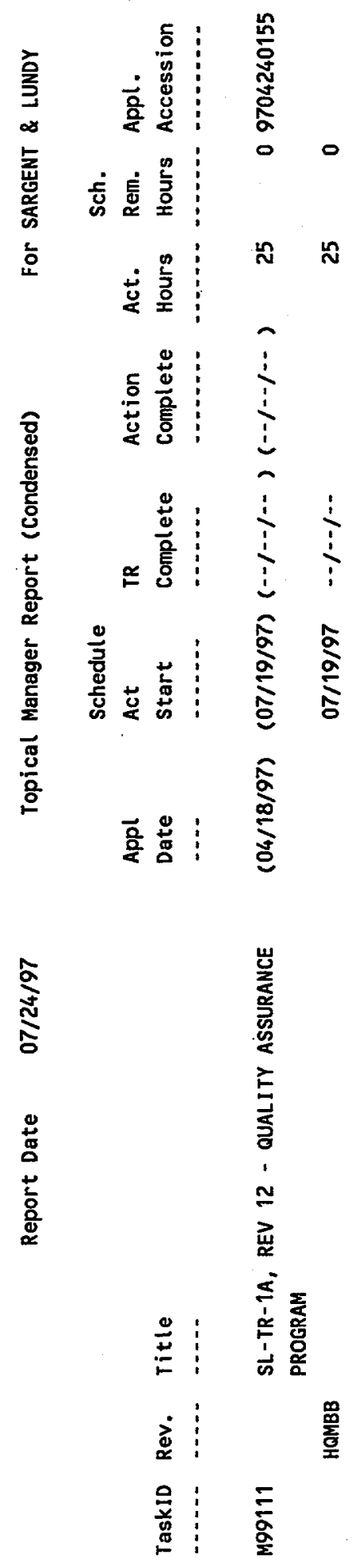


\begin{tabular}{|c|c|c|c|c|c|c|c|c|c|}
\hline \multirow[b]{2}{*}{ TaskID } & \multirow[b]{2}{*}{ Rev. } & Report Date & Topical & \multicolumn{3}{|c|}{ Manager Report (Condensed) } & \multicolumn{3}{|c|}{ For SIEMENS } \\
\hline & & Title & $\begin{array}{l}\text { Appl } \\
\text { Date }\end{array}$ & $\begin{array}{l}\text { Schedule } \\
\text { Act } \\
\text { Start }\end{array}$ & $\begin{array}{l}\text { TR } \\
\text { Complete }\end{array}$ & $\begin{array}{l}\text { Action } \\
\text { Complete }\end{array}$ & $\begin{array}{l}\text { Act. } \\
\text { Hours }\end{array}$ & $\begin{array}{l}\text { Sch. } \\
\text { Rem. } \\
\text { Hours }\end{array}$ & $\begin{array}{l}\text { Appl. } \\
\text { Accession }\end{array}$ \\
\hline -...- & $\cdots$ & $\cdots$ & $\cdots$ & $\cdots \cdots$ & n...... & (n) & (n)..... & -......... & - ............. \\
\hline M84245 & & $\begin{array}{l}\text { EMF-92-116 P - GENERIC MECHANICAL DESIGN } \\
\text { CRITERIA FOR PWR FUEL DESIGNS. }\end{array}$ & $(08 / 03 / 92)$ & $(05 / 07 / 94)$ & $(--1--1--)$ & $(10 / 03 / 97 T)$ & 164 & & 29208050140 \\
\hline & SRXBA & & & $05 / 07 / 94$ & 10/03/97 & & 164 & 12 & 2 \\
\hline M85182 & & $\begin{array}{l}\text { EMF-92-139(P), VOL } 1 \text { - REALISTIC LOCA } \\
\text { ECCS EVALUATION MODEL METHODOLOGY FOR } \\
\text { PWR LARGE BREAK LOCA ANALYSIS, 12/92 }\end{array}$ & $(12 / 01 / 92)$ & $(09 / 11 / 93)$ & $(-/--/-\infty)$ & $(01 / 26 / 98 \mathrm{~T})$ & 90 & & 09212040297 \\
\hline & SRXBB & & & $09 / 11 / 93$ & $--/--/--H$ & & 90 & & 0 \\
\hline M92881 & & $\begin{array}{l}\text { EMF-95-084(P) - PWR NEUTRONICS DESIGN } \\
\text { CODE/CODE SYS EVAL \& VALIDATION }\end{array}$ & $(06 / 19 / 95)$ & $(--/--/--)$ & $(--1--1,-)$ & $(12 / 31 / 98 T)$ & 0 & & 19506290221 \\
\hline & SRXBB & & & $--/--1--$ & $12 / 31 / 98$ & & 0 & 31 & 1 \\
\hline M94336 & & $\begin{array}{l}\text { EMF-1125, SUPP 1, APP C - ANFB CRITICAL } \\
\text { POWER CORRELATION APPLICATION FOR } \\
\text { CO-RESIDENT FUEL }\end{array}$ & $(11 / 30 / 95)$ & $(02 / 03 / 96)$ & $(--1--1-\cdots)$ & $(12 / 31 / 97 \mathrm{~T})$ & 48 & & 49512050173 \\
\hline & & & & $02 / 03 / 96$ & $--/--1--$ & Unassigned & 0 & 0 & 0 \\
\hline & ..... & & & $02 / 24 / 96$ & $06 / 30 / 96 \mathrm{C}$ & Suppressed & 38 & $\cdots$ & \\
\hline & PGEBB & & & $\cdots /--/ \cdots$ & $12 / 31 / 97$ & & 0 & 34 & \\
\hline & SRXBA & & & $02 / 03 / 96$ & 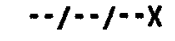 & & 10 & $\cdots$ & \\
\hline & SRXBB & & & $02 / 06 / 96$ & $02 / 14 / 96 C$ & & 0 & $\cdots$ & \\
\hline
\end{tabular}


TaskID Rev. Title

r..... ..... -....

M95381

ANF-91-048, SUPPL 1-BWR JET PUMP MODEL REV. FOR RELAX

PGEBB

SRXBA

SRXBA

SRXBA

M96729

EMF-85-74(P), REV, 0, SUPPL 1 - RODEX2A (BWR) FUEL ROD THERMAL-MECH EVAL MODEL: VALIDATION

$\tilde{\omega}$ SRXBA

$M 97519$

XN-NF-82-20(P)，REV.1， SUPPL 6 EXEM/PWR LG BREAK LOCA ECCS TOODEE2 UPDATES

PGEB

SASG

SRXBC

SRXBC

\begin{tabular}{|c|c|c|c|c|c|c|}
\hline & Schedule & & & & Sch. & \\
\hline $\begin{array}{l}\text { Appl } \\
\text { Date }\end{array}$ & $\begin{array}{l}\text { Act } \\
\text { start }\end{array}$ & $\begin{array}{l}\text { TR } \\
\text { Complete }\end{array}$ & $\begin{array}{l}\text { Action } \\
\text { Complete }\end{array}$ & $\begin{array}{l}\text { Act. } \\
\text { Hours }\end{array}$ & $\begin{array}{l}\text { Rem. } \\
\text { Hours }\end{array}$ & $\begin{array}{l}\text { Appl. } \\
\text { Accession }\end{array}$ \\
\hline & $\ldots$ & - & $\cdots$ & & -4 & \\
\hline
\end{tabular}

$(05 / 06 / 96)(05 / 18 / 96)(--/--/--)(09 / 30 / 97 T)$ 249

359605090268

$08 / 31 / 96 \quad 09 / 30 / 97$

$06 / 15 / 96 \quad 07 / 30 / 97$

$05 / 18 / 96 \quad 02 / 11 / 97 \mathrm{C}$

$07 / 27 / 96 \quad 02 / 12 / 97 \mathrm{C}$

$(09 / 20 / 96)(05 / 24 / 97)(--/ \cdots / \cdots)(01 / 31 / 98 \mathrm{~T})$

18

509609250030

$05 / 24 / 97 \quad 01 / 10 / 98$

18

50

$(12 / 20 / 96)(01 / 18 / 97)(--/ \cdots / \cdots)(03 / 31 / 98 \mathrm{~T})$

$\begin{array}{ll}03 / 15 / 97 & 03 / 31 / 98 \\ 03 / 15 / 97 & 02 / 13 / 98 \\ 01 / 18 / 97 & 10 / 24 / 97 \\ 03 / 01 / 97 & 09 / 26 / 97\end{array}$

$\begin{array}{rr}2 & 37 \\ 21 & 100 \\ 18 & 15 \\ 50 & 28\end{array}$


Topical Manager Report (Condensed)

Schedule

Task10 Rev. Title

M98478

ANF-1125(P), SUPPL. 1, APP. D - ANFB CRITICAL POWER CORRELATION UNCERTAINTY FOR LIMITED DATA SETS.

PGEBB

SRXBA

SRXBB

\begin{tabular}{|c|c|c|c|c|c|c|}
\hline & Schedule & & & & Sch. & \\
\hline $\begin{array}{l}\text { Appl } \\
\text { Date }\end{array}$ & $\begin{array}{l}\text { Act } \\
\text { Start }\end{array}$ & $\begin{array}{l}\text { TR } \\
\text { Complete }\end{array}$ & $\begin{array}{l}\text { Action } \\
\text { Complete }\end{array}$ & $\begin{array}{l}\text { Act. } \\
\text { Hours }\end{array}$ & $\begin{array}{l}\text { Rem. } \\
\text { Hours }\end{array}$ & $\begin{array}{l}\text { Appl. } \\
\text { Accession }\end{array}$ \\
\hline
\end{tabular}

$(04 / 18 / 97)(05 / 03 / 97)(--/--/--)(02 / 28 / 987)$

1529704280162 
TaskID Rev. Title

r................

M82099

WCAP-10924-P-REV. 2-VOLUME 2-ADDENDUM 3 - LARGe bREAK LOCA BEST ESTIMATE

METHODOLOGY - UPPER PLENUM INJECTION MODEL

\begin{tabular}{|c|c|c|c|c|c|c|}
\hline & Schedule & & & & Sch. & \\
\hline $\begin{array}{l}\text { Appl } \\
\text { Date }\end{array}$ & $\begin{array}{l}\text { Act } \\
\text { Start }\end{array}$ & $\begin{array}{l}\text { TR } \\
\text { Complete }\end{array}$ & $\begin{array}{l}\text { Action } \\
\text { Complete }\end{array}$ & $\begin{array}{l}\text { Act. } \\
\text { Hours }\end{array}$ & $\begin{array}{l}\text { Rem. } \\
\text { Hours }\end{array}$ & $\begin{array}{l}\text { Appl. } \\
\text { Accession }\end{array}$ \\
\hline & $\ldots$ & $\ldots . .$. & .......... & & & \\
\hline
\end{tabular}

$(04 / 30 / 91)(08 / 21 / 93)(--/--1--)(08 / 31 / 97 \mathrm{~T}) 166$

09104290088 SRXBB

$08 / 21 / 93 \quad 08 / 31 / 97$

WCAP-13246-P \& WCAP-13412-NP - W-GOTHIC, A COMPUTER CODE FOR ANALYSES OF THERMAL HYDRAULIC TRANSIENTS FOR NUCLEAR PL

SCSB

U

$M 92312$

WCAP-11992 - JOINT WEST. OWNERS GROUP/WEST. PROG: ATWS RULE ADMIN. PROCESS

PGEBA

SPSBB

SRXBB

M93299

WCAP-14404-P, METHODOLOGY FOR INCORP. HOT LEG NOZZLE GAPS INTO BASH
$(01 / 27 / 96)(\cdots / \cdots / \cdots)(12 / 31 / 971)$

$(07 / 31 / 92)$

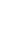

\author{
$01 / 27 / 96 \quad 07 / 02 / 97 x$
}

$(05 / 02 / 95)(05 / 20 / 95)(--/--/--)(10 / 12 / 98 \mathrm{~T})$

$\begin{array}{ll}12 / 21 / 96 & 07 / 31 / 97 \\ 06 / 24 / 95 & 10 / 12 / 98 \\ 05 / 20 / 95 & 07 / 01 / 97 C\end{array}$

$(07 / 26 / 95)(08 / 26 / 95)(--/ \cdots / \cdots)(08 / 31 / 05 T)$

$08 / 26 / 95 \quad 08 / 31 / 05$
166

0

249

09208040270

249

332

359505100058

$17 \quad 3$

$189 \quad 33$

$126 \quad \ldots$

$11 \quad 09508070096$

110 

ESTIMATE LARGE BREAK LOCAMETHODOLOGY (WESTINGHOUSE PWR'S WITH UPPER PLEMUM INJECT

$(08 / 31 / 95)(11 / 18 / 95)(--/--/--)(01 / 26 / 98 T)$

829509070056

WCAP-14219 \& WCAP-14432 - RV CLOSURE HEAD PENETRATION SUPPLEMENTAL ASSESSMENT OF NRC SER ISSUES.

EMCBA

$\widetilde{\sigma}$

M94338

WCAP-14483 - GENERIC METHODOLOGY FOR EXPANDED COLR.

SRXBB

M95847

WCAP-14486, REV 1 - ECCS HOT LEG RECIRC. ELIMINATION FOR WEST. $3 \& 4$ LOOP DESIGN

67

82

NSSS.

M96061 WCAP - 13360P - WEST. DYNAMIC ROD WORTH MEASUREMENT TECHNIQUE
$(07 / 10 / 96)(07 / 20 / 96)(--/--/ \cdots)(09 / 05 / 971)$

$10 / 19 / 96 \quad 08 / 29 / 97$

$07 / 20 / 96 \quad 08 / 30 / 97$
$(10 / 27 / 95)(06 / 07 / 97)(--/--/--)(12 / 31 / 971)$

$--1--1-\cdots+--1--1 \cdot-$

$06 / 07 / 97 \quad 12 / 31 / 97$

71

199511210166

$(12 / 01 / 95)(01 / 27 / 96)(-\cdots / \cdots / \cdots)(01 / 01 / 98 T)$

$01 / 27 / 96 \quad-\cdot / \cdots / \cdots H$

0

9606190238 


$$
\text { 變 }
$$

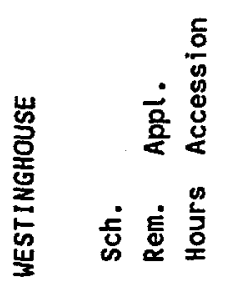
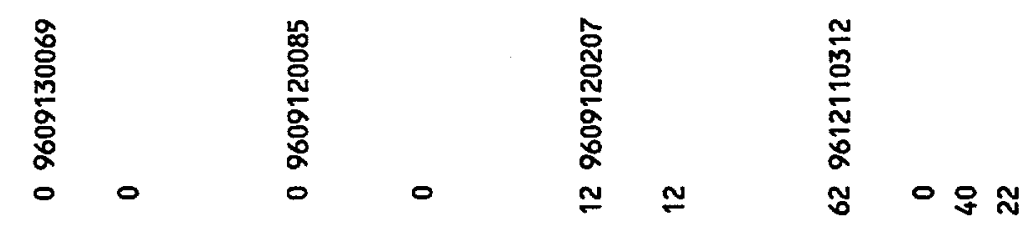

옹

호

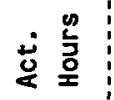

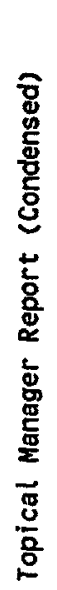

唩影

0000

$\sim N$

$\stackrel{n}{\simeq}$

$\circ 0-$



is

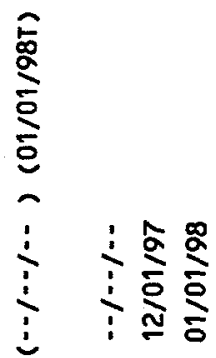

홍

$\stackrel{i}{i} \quad \frac{1}{i}$

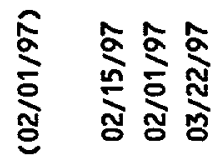

$\stackrel{5}{\vdots}$

:

㠃

高

초

産 突㠃

홍

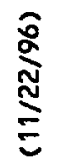

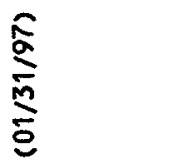

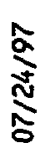

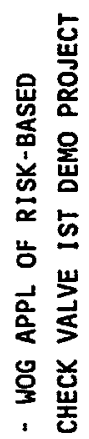

品ㅇ-

鱼少

옹

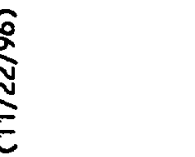

옹

홀

蓠

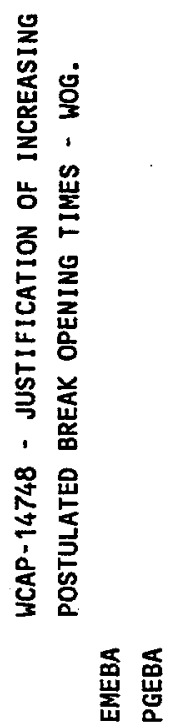

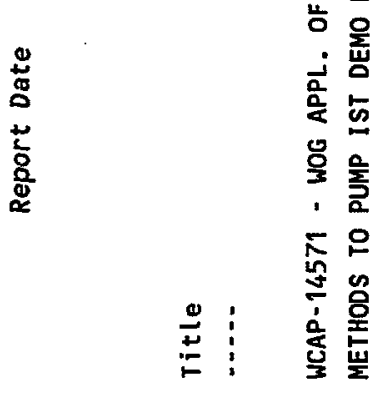

종

点点

울

홀

ษ

这㗜

宸

峞

总

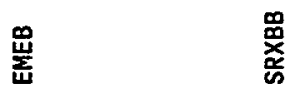

$\frac{\text { : }}{\frac{0}{2}}$

$\frac{\substack{2 \\ \frac{2}{2}}}{2}$

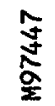

旤 
Appl Act TR Action Act. Rem. Appl.

Date Start Complete Complete Hours Hours Accession

M98666 WCAP-14565, REV. 0 - "VIPRE-01 MODELING \& QUALIF FOR PWR NON-LOCA THERMAL-HYDRAULIC SAFETY ANALYSIS SRXB

$M 99107$

WCAP-14882, REV 0 - RETRAN-02 MODELING AND QUAL FOR WEST. PWR NON-LOCA SAFETY ANALYSES

$\stackrel{\infty}{\infty}$

M99235 REVIEW OF WEST. OVATION DISTRIBUTED CONTROL \& INFO SYSTEM
-...
-.......

$(04 / 21 / 97)(--/--/-\cdots)(--/--/--)(--/--/--)$

0 9704300008 $\cdots /--/ \cdots \quad \cdots /--/ \cdots \quad$ Unassigned
HICBA

HICBA

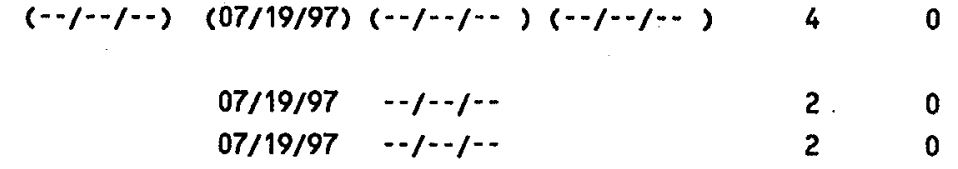



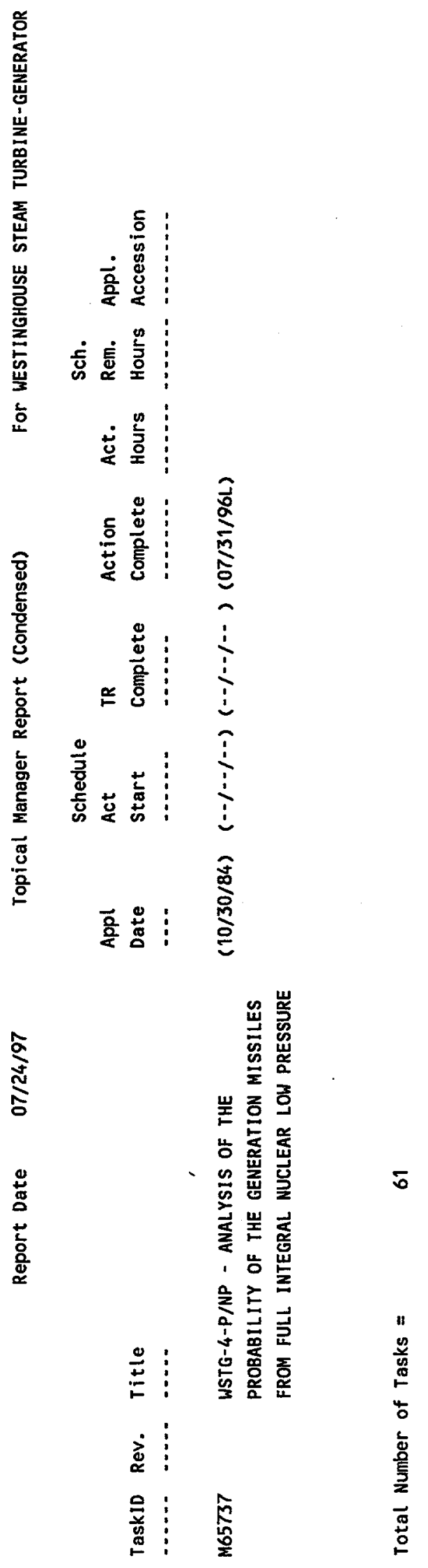